\author{
АЛЕКСАНДРА Б. ВРАНЕШ* \\ Универзитет у Београду \\ Филолошки факултет
}

\title{
БИБЛИОГРАФИЈА О ДОБРИЦИ ЋОСИЋУ
}

Персонална библиографија, као слика живота и рада истакнутих „јединоплеменика" не би ли се „роду познатије учинило”, како је још у другој деценији XIX века, у име „народне чести и ползе”, писао Георгије Магарашевић, поуздан је и чврст ослонац за утврђивање научних, стручних, уметничких, друштвених резултата аутора, истовремено и потпора изради завичајне и националне библиографије. Библиографија Добрице Ћосића истовремено је и лична и друштвена хроника.

Кључне речи: Ћосић, Добрица, библиографија, персонална библиографија, национална библиографија, завичајна библиографија.

У другој деценији XIX века, у име „народне чести и ползе”, Георгије Магарашевић (1819: 95) у Новинама Сербским донео је своје виђење персоналне библиографије и тако постао њен идејни зачетник у српском народу. Нагласио је потребу за њом у свакој, па и нашој средини. У тексту Биоірафическе черие славни Сербаља записао је, у жару свога правдољубивог и поносног родољубља, да „совершена биографија” захтева „изображенија ума [...], человјекопознанства и способности” и стога моли све родољубиве Србе да у име „народне чести и ползе” саопште све што знају о „славнима у роду нашем људма и њиови дјели да се то у Љетопис Сербску стави и роду познатије учини" (1819: 95). У том, могло би се рећи, „програмском” тексту, Магарашевић моли своје будуће сараднике да му шаљу прилоге о животу и делима нарочито Захарија Орфелина, Јована Живковића, Јована Мушкатировића, Григорија Терлајића и Јована Павловића.

Магарашевић је осоколио своје савременике да пишу о животу и делу својих „јединоплеменика”, али је Димитрије Давидовић биобиблиографију код Срба прво профилисао. Потврђујући своје словенско опре-

*aleksandra.vranes@gmail.com 
дељење, Давидовић у Новинама сербским, у рубрици Славенстиво, српској читалачкој публици представља личност и дело чешког филолога, историчара књижевности и песника Јосифа Добровског (1753-1828), који је „ускрснуо бит словенства у Европи” и кога и библиограф Петар Иванович Кепен сматра својим учитељем (1836: 3), наводећи наслове књига на језику оригинала, немачком, латинском или чешком, и упоредо на српском.

Тридесетих година XIX века истакнути „славено-сербски” списатељи Јоаким Вујић и Милован Видаковић као да су прихватили сугестије Магарашевића и пописали су своје књиге. Вујић је то учинио 1826. године у, анонимно у Пешти издатој, књижици Verzeichniss deren verfassten, und theils ubersetzten und in der konigl. hung. Universitats Buchdruckerey zu Ofen abgedruchken und erschienen Werke, за коју je, мада је писана у трећем лицу, ауторство утврдио Антониј Арнот у своме Маїазину за хуgожесииво, књижесииво и моgу, а затим га потврдили Јован Скерлић и Павле Поповић. Детаљно, ову брошуру скромног обима (свега 22 стране) описао је Душан Панковић, називајући је „обичним тефтером" за 19 штампаних и 23 рукописне јединице. И у занимљивој, сентименталистички писаној аутобиографији Животоооиисаније и ирезвичајна юеі̄ова ирикљученија, објављеној у Карлштадту 1833. године, последње, петнаесто, поглавље Назначеније они моји књиіа које сам ја оти

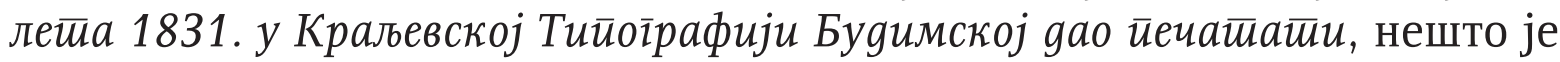
потпунија „аутоперсонална" библиографија, која обухвата 22 штампане и 23 рукописне књиге (Панковић 1982: 68). Овај преглед Вујићевог списатељског рада није значајан због обухвата библиографског описа, који је сасвим скроман (наслов, година издања, место и штампарија), већ због пропратног „индекса” духовних и световних лица заслужних за штампање његових „умотворенија”, јер је овај „литератор, писмознатељ и путешествоватељ, [...] књижевни торбар" (Лесковац 1977: 81) зависио од гостољубивости познатих и непознатих, издржавајући се од милостиње богатих и владајућих и од продаје својих књига.

И други значајни прозаиста тога доба, Милован Видаковић, сврстао се, мада скромним прилогом, у ред библиографа. Без намере да начини библиографију, он је, у Преgисловију Пушешесиввија у Јерусалим, издатог 1834. године у Будиму, прибележио 14 штампаних и 6 рукописних дела, како би, доказујући своју списатељску плодотворност, побио негативне судове Вука и „вуковаца”.

Мале персоналне библиографије, које су попут уникатних медаљона уклопљене у Шафариково дело Geschichte der Serbischen Literatur, настале пре Вујићевих и Видаковићевих библиографских вежби, до данас су остале непревазиђени ослонац бројним истраживачима живота 
и рада Доситеја Обрадовића, Лукијана Мушицког, Николаја Шимића, Вићентија Ракића, Милована Видаковића, Атанасија Стојковића, Глигорија Јакшића и других.

Најчешће су биобиблиографске белешке бивале у Новинама сербским, Летиойису сербском и Поэунавци, потом у Колу, листу за забаву и књижевност, уредника Данила А. Живаљевића (1889: 232-236), Гоguшњаку Срйске краљевске акаяемије, Просвеиином ілласнику (1888: X-XIII, 624), у ХХ веку у Јужнословенском филологу, Прилозима за книневносй, језик, истиорију и фолклор, Књижевном северу и Сйраном ирреілеgу, и намера им је била да утичу „на организовање научног рада и ширење и одржавање научног интереса у нас" (Прилози 1921-23: III).

Након Другог светског рата интересовање библиографа се, чешће него што је то бивало раније, усмерава ка угледним и заслужним појединцима, те је број и квалитет персоналних библиографија нагло порастао. Био је то и поуздан пут за стварање чврстог ослонца у изради завичајне и националне библиографије, у земљи чија је национална библиотека у рату изгорела до темеља. Ипак, обухватне персоналне библиографије остале су малобројне, и међу њима се могу издвојити оне посвећене Јакшићу, Десанки, Настасијевићу, Андрићу.

Овом кругу придружује се и библиографија Добрице Ћосића. Обухватна, проверена, вишеаспектна библиографска истраживања нису везивана за дело Добрице Ћосића. Углавном су објављиване селективне библиографије као прилози појединим издањима. Наговештај касније библиографске посвећености Дејана Вукићевића делу Добрице Ћосића виђен је у његовој библиографији која обухвата период после 1990. (објављена је 2008. у издању посвећеном савременој српској прози, Народне библиотеке „Јефимија” у Трстенику). Две године касније Дејан Вукићевић, у издању Службеног гласника, једне од ретких издавачких кућа које публикују ову врсту радова, објављује потпунију библиографију у коју су укључени ауторски радови Добрице Ћосића и радови о њему. Стваралаштво Добрице Ћосића представљено је у хронолошком следу, у складу са принципима које је поставио још Стојан Новаковић, намеран да прати поступан развој књижевности. За систематизацију радова о Добрици Ћосићу изабран је азбучни поредак по презимену аутора. Библиографија није опремљена уводном студијом, која би садржала биографске податке и пружила детаљнији увид у структуру библиографије, већ само кратком општом напоменом. И у напомени, а и сама библиографија то показује, види се да се библиограф определио за детаљан опис који омогућава Међународни стандард за библиографски опис публикација. Вукићевић у уводној напомени захваљује колегама библиотекарима, али посебну захвалност упућује кћерки Добрице Ћо- 
сића, Ани Вукић Ћосић, захваљујући чијој љубазности му је био омогућен приступ рукописима, чланцима и књигама, нарочито у преводу, које други нису поседовали. Библиографија садржи 291 јединицу монографских публикација, 92 јединице превода књига на 26 језика, девет јединица некњижне грађе, један драмски текст у серијској публикацији, 65 проза у серијским и монографским публикацијама, 77 превода прозе у серијским и монографским публикацијама, 433 текста у серијским и монографским публикацијама, 188 интервјуа и анкета, 1062 текста о Добрици Ћосићу, што чини укупно 2425 јединица Вукићевићеве библиографије. Да је библиографија нумерисана по засебним целинама, а не јединствено, како је овде случај, јасније би читаоцу стављала до знања да је Ћосићевих ауторских јединица скоро исто онолико колико радова о његовом делу, написаних од стране најмање, колико се може поуздати у моје бројање, 564 аутора. Опремљена индексима имена, неразрешених иницијала и шифара, наслова текстова, наслова серијских публикација и језика превода, без предметног индекса, она тежи обухватном библиографском сагледавању Ћосићевог стваралаштва, мада, како каже њен аутор, у њу нису укључени новински текстови „које је аутор сматрао сувише ефемерним (кратке изјаве и коментари, изводи из интервјуа, прикази књига од неколико реченица)".

Пре библиографије Дејана Вукићевића у монографским публикацијама као прилози објављивани су само селективни прегледи издања дела Добрице Ћосића. Први пут библиографија се појављује уз Корене у библиотеци Срйска књижевносй у сйо књиїa, у редакцији Светлане Велмар Јанковић (1964) и понавља се у следећим издањима (1970). Уз трећу књигу Деоба, у Библиотеци Срйска књижевносй: роман (књ. 35) објављена је библиографија Изяања Корена, коју је сачинио Гојко Тешић. Библиографија Изяања Корена понавља се и у издању Рада (Библиотека Дом u школа), које је приредио Петар Пијановић. Исти принцип предметно усмерене библиографије Гојко Тешић примењује и у прилогу Изgања Деоба у истој едицији (књ. 36). Изgања романа Далеко је сунще и Превоgи сакупљени су трудом Љубише Јеремића (Дела Добрице Ћосића; Коло 1, књ. 1, 2000). Преглед Изабрана лишератиура приредио је Мирослав Егерић у књ. 36 исте едиције, потом Милан Радуловић уз издање Корена (1997, 2004). Уз Hagy u акuију библиографске путоказе је пружио Триво Инђић (Дела Добрище Ћосића; Коло 1, књ. 7, 2000); уз Писие моїа века Библиоірафске референще је сачинила Ана Ћосић Вукић (Библиотека Два сйолећа, књ. 3, 2004); издање Разі̄овора и животиойиса, које је приредио Радован Поповић, доноси и Библиоірафске йоgайке о разі̄оворима (Дела Добрище Ћосића; Коло 24, књ. 4, 2005); док Милорад Екмечић и Василије Крестић приређују Найомене и библиоірафске референце уз текст књиге 
Срйски gуховни йрост̄ор (2005). Библиографија првих издања дела Добрице Ћосића и Селективна библиографија књига о делима и животу Добрице Ћосића прилог је и књизи Миливоја Павловића Оїлеgало Добрище

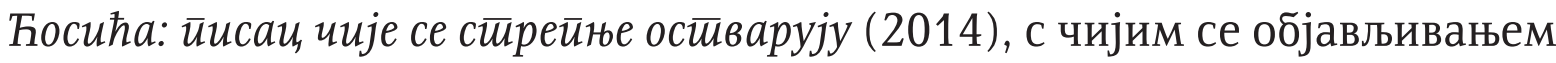
сложио и сам Ћосић. Ниједна преведена књига не доноси библиографске прегледе.

Сваки од пометнутих библиографских прилога, нарочито библиографију из 2014, карактеришу прегледност, систематичност и тачност, подстичући на будућа истраживања, што не чуди с обзиром на интензитет Ћосићеве продукције.

Свака библиографија подразумева ширење комуникацијског хоризонта читаоца и ауторовог дела. Богатство Ћосићевог књижевног живота и јавног друштвеног ангажовања очекује нова библиографска прегнућа.

\section{Литература}

Vukićević, Dejan. „Selektivna bibliografija Dobrice Ćosića: (od 1990)”. Zbornik 25. književnih susreta Savremena srpska proza. Trstenik: Narodna biblioteka "Jefimija”, 2009, 183-223. Št.

Живаљевић, Данило А. (ур.). Коло: листи за забаву и књижевности. Београд: [б. и.], год. 1, бр. 14, 1889. Шт.

Кепен, Петар Иванович. „Литература славјанских народов : писмо к редактору Журнала Министарства Народнаго Просвјештенија 1836. год." Шт.

Лесковац, Младен. „Боравак Јоакима Вујића у Фрушкој гори године 1842.”

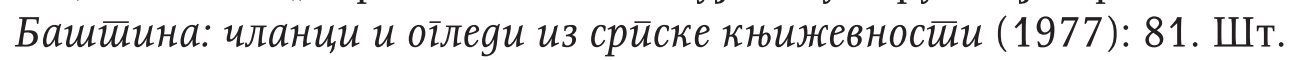

Магарашевић, Георгије. „Биографическе черте славни Сербаља”. Новине сербске, том 1, књ. 157 (1819): 95. Шт.

Павловић, Миливоје. „Библиографија првих издања дела Добрице Ћосића; Селективна библиографија књига о делима и животу Добрице Ћосића". Оїлеgало Добриие Ћосића: иичсаи, иије се сиирейње остиварују. Београд: Новости, 2014, 229-232. Шт.

Панковић, Душан. Срйске библиоірафије: 1766-1850. Београд: Народна библиотека Србије; Нови Сад: Библиотека Матице српске, 1982. Шт.

Поповић, Павле (ур.). Прилози за књижевности, језик, истиорију и фолклор. Београд: [б.и.], књ. 1-3, 1921-23. Шт.

Поповић, Стеван Д., и Никола Ј. Петровић (ур.). Просвейни іласник: службени

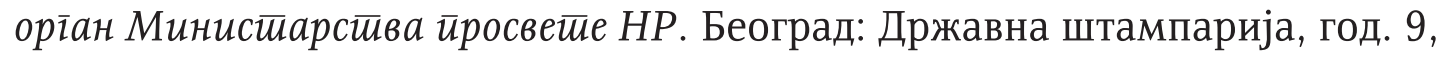
бр. 1-24, 1888. Шт. 


\section{ИЗВОРИ}

Ћосић, Добрица. Корени: роман. [Предговор и редакција Светлана Велмар-Јанковић]. Нови Сад: Матица српска; Београд: Српска књижевна задруга, 1964.

Ćosić, Dobrica. Koreni: roman. [Predgovor Svetlana Velmar-Janković]. Novi Sad: Matica srpska; Beograd: Srpska književna zadruga, 1970. Št.

Ćosić, Dobrica. Deobe. Bibliografiju sačinio Gojko Tešić. Beograd: Nolit, 1981a. Št.

Ćosić, Dobrica. Koreni. Bibliografiju sačinio Gojko Tešić; [pogovor i napomene napisao Miroslav Egerić]. Beograd: Nolit, 1981b. Št.

Ćosić, Dobrica. Koreni. Bibliografiju sačinio Gojko Tešić; [predgovor Petar Tijanović]. Beograd: Rad, 1982. Št.

Ćosić, Dobrica. Koreni. Pripremio i propratne tekstove napisao Milan Radulović. [1. izd.]. Beograd: Zavod za udžbenike i nastavna sredstva, 1997. Št.

Ćosić, Dobrica. Daleko je sunce. Ljubiša Jeremić (prir.). Beograd: Filip Višnjić, 2000a. Št.

Ćosić, Dobrica. Nada i akcija. Trivo Inđić (prir.). Beograd: Filip Višnjić, 2000b. Št.

Ćosić, Dobrica. Koreni. Priredio i propratne tekstove napisao Milan Radulović. 2. izd. Beograd: Zavod za udžbenike i nastavna sredstva, 2004a. Št.

Ćosić, Dobrica. Pisci moga veka. Ana Ćosić Vukić (prir.). Beograd: Zavod za udžbenike i nastavna sredstva, 2004b. Št.

Ćosić, Dobrica. Razgovori i životopis. Radovan Popović (prir.). Beograd: Filip Višnjić, 2005. Št.

Ćosić, Dobrica, i dr. Srpski duhovni prostor. Beograd: Nova Evropa, [2005?]. Št.

\section{Aleksandra B. Vraneš}

\section{A BIBLIOGRAPHY ON DOBRICA ĆOSIĆ}

\section{Summary}

A personal bibliography, as an illustration of the life and work of prominent "fellow countrymen" in order to "enlighten the people", as Georgije Magarašević wrote in the 1810s, in the name of the "popular honour and use", is a reliable and proven basis for the ascertaining of an author's academic, professional, artistic and social results, and simultaneously a support to the compilation of an area and national bibliography. A bibliography on Dobrica Ćosić is both a personal and social chronicle. 